\title{
EGFR NM_005228.3:c.2236_2250del15
}

National Cancer Institute

\section{Source}

National Cancer Institute. EGFR NM 005228.3:C.2236 2250de/15. NCI Thesaurus. Code C98539.

A deletion of 15 nucleotides from the coding sequence of the EGFR gene from position 2236 through 2250. 